\title{
DE LOEBOES IN MANDAILING
}

\author{
DOOR
}

J. KREEMER.

I. Bewoners. Voorkomen. Geaardheid. Vofding. Kleeding.

W APENEN. MUZiek.

Zooals bekend, vindt men de Loeboesche nederzettingen in de afdeelingen Padang Lawas (Oeloe Baroemoen) en Mandailing. In de volgende bladzijden worden alleen de laatsten ter sprake gebracht: Zij wonen min of meer geisoleerd aan den voet en op de westelijke hellingen van het Barisan gebergte, dat de beide genoemde landstreken scheidt.

Hun zielental bedraggt thans 1925 over een elftal nederzettingen verdeeld [zie achterstaanden overzichtstaat]. In 1891 bedroeg dat cijfer volgens den toenmaligen controleur Th. A. L. Heyting 2033; het werd in 1884 door den controleur P. A. L. L. van Dijk op pl. m. 1455 geschat.

In ontwikkeling, taal en voorkomen wijken zij belangrijk af van hunne buren, zoodat zich vanzelf de vraag opdoet naar hun vermoedelijke herkomst. Het is dan ook niet te verwonderen, dat de verschillende schrijvers, die ons omtrent de Loeboe's hebben ingelicht, met zekere voorkeur naar een antwoord op die vraag hebben gezocht. ${ }^{1}$ Sommigen (E. Netscher) rekenen hen te behooren tot de autochtoneu van Sumatra, anderen (J. B. Neumaun) achten waarschijnlijk, dat zij van het schiereiland Melaka af komstig zijn, terwijl weer anderen (T. J. Willer) in hen afstammelingen zien van Minangkabausche Maleiers. Intusschen blijven al dergelijke onderstellingen, zooals voor de hand ligt, van weinig waarde, zoolang omtrent de raskenmerken der grootere volkstammen op Sumatra en elders in ouzen Archipel nog zoo weinig met zekerheid bekend is.

1 Voor de Loeboe-litteratuur raadplege men M. Joustra, Litteratuuroverzicht der Bataklanden.

Dl. 66 . 
Volgens de volksverhalen in Mandailing in omloop zouden de Loeboe's in een ver verwijderde periode uit Padang Lawas naar Mandailing ziju verhuisd, onder aanvoering van hun hoofd Singa Tandang. Deze emigratie zou hebben plaats gehad tijdens het bestuur van Soetan Koemala Jang Dipatoean, den eersten Radja uit het stamhuis Kota Siantar. Deze ging - zóó verhaalt de legende met Singa Tandang een compromis aau, waarbij de Radja bedoug, dat het Loeboe-hoofd beloven moest hem alles te zullen geven, wat hij van hem verlangde, terwijl de Loeboe's de verzekering erlangdeil, dat hun adat niet zou wordeu geschonden en dat zij nimmer tot slaven zouden worden gemaakt. Op zekeren dag vond de Radja een soort kapmes (soerik), dat uit den hemel was gevallen en $S i$ Ondam-Ondam werd genoemd. ${ }^{1} \mathrm{Hij}$ droeg toen aan Singa T'andang op een stuk rotan te zoeken uit slechts één lid bestaande en breed genoeg om er een scheede voor dat hemelsche mes van te kunnen maken. Het gelukte Singa Tandang echter niet om aan die opdracht te voldoen. Hierdoor moest hij ontrouw worden aan de voorwaarden van bovenbedoeld compromis en, bevreesd voor de gevolgen, vluchtte hij daarom met een deel der Loeboes naar de landschappen Oeloe en Rau.

Het is wellicht naar aauleiding van deze en andere dergelijke volkstraditiën, dat sommige schrijvers eenheid van afstamming hebben verondersteld van de Loeboe's en de in het zuiden van Klein-Mandailing nog wonende Oeloe's. Gaat men echter na, dat de volksinstellingen der Loeboe's en Oeloe's hemelsbreed van elkander verschillen, dan bestaat er voor een verwantschap tusschen die beide volksstammen - zooals b.v. de heer P. A. L. E. van Dijk veronderstelde - m. i. geen aanuemelijke grondslag. ${ }^{2}$ Ook uit hunne talen is die verwantschap niet af te leiden, wel is waar bevatten ze beide

1 Dit uit één stuk ijzer gesmeed kapmes behoort thans nog tot de z.g. poesaka's van het koeria-hoofd van Kota Siantar.

2 De Oeloe's hebben het moederrecht met de adat kamanakan, de instelling der harta poesaka enz. geheel analoog met de volksinstellingen op Sum. W.K. Zij zijn uit het Rau'sche afkomstig, waar men nog dezelfde 3 soekoe's (Poengkoet, Mandailing en Kandang Kapoek) terugvindt, waartoe de Oeloe's zich rekenen te behooren. Bij onze bestuursvestiging in Mandailing werd Oeloe van de tegenwoordig in Rau gelegen laras Padang Mantinggi afgescheiden en bij Mandailing getrokken. Hun taal is het z. g. Bovenlandsch Maleisch met dialectische afwijkingen. Zoo gaan hier - om ons tot dit ééne voorbeeld te bepalen - de eindnasalen $m, n$ en $n g$ over in $p, t$ en $k$. Dus ajam = ajop; dus ikan, kain, ratjoen $=i k e t$, kait, ratjoet; dus arang, andjing, toeloeng $=$ arak, andjik, toeloek enz. 
vele Maleische elementen, maar terwijl het Oeloesch m. i. niet auders is dan een tongval vau het Minangkabau Maleisch, is het Loeboesch veelmeer een mengelmoes van Mandailingsche, Maleische en andere (?) woorden, die voor oningewijden reeds daarom onverstaanbaar klinken, omdat de Loeboe de $r$ niet uitspreekt en daarvoor een klank gebruikt, die vóór in den mond wordt uitgesproken en het midden houdt tusschen onze $b . w$. en $v{ }^{1}$

Volgens sommige schrijvers (o. a. Th. A. L. Heyting) zouden de Loeboe's "tot slavernij gedoemd" ziju geweest. Dit schijnt mij echter niet juist te zijn, wèl waren zij schatplichtig aan de Radja's van Kota Siantar, maar geen slaven, hetgreen o. a. hieruit blijken kan, dat bij de vrijverklaring der slaven in Mandailing voor een Maudailingschen slaaf $f 60$ werd betaald en voor een Loeboe slechts de helft.

Wil men de Loeboe's naar aard en voorkomen beschrijven, dan dient als het meest kenmerkend allereerst gewezen op hun armzalige en onzindelijke verschijuing als gevolg van hun armelijke levenswijze. Vaak zijn ze met afzichtelijke huidziekten behept en voorzonver ze kleêren dragen, hangen hun die bij lappen aan het lijf. Verder verspreiden zij een eigenaardigen hoogst onaangenamen geur.

Opmerkelijk is hun groote afkeer van water; niet alleen dat zij zich hoogst zelden baden, maar zij mijden ook zooveel mogelijk het wonen nabij de rivieren. De regel dat alle Inlanders zwemmen kunnen vindt in iederen Loeboe een uitzonderiug.

Lui en onverschillig van aard, zijn ze verder zeer traag in humne bewegingen. Ook zijn ze in hooge mate zorgcloos voor den dag van morgen.

Tegenover vreemden toonen zij zich schuw en bedeesd; spreekt men hen aan, dan zien ze den audereu kant uit. Zijn ze met elkaar in gesprek, dau werken ze opvallend sterk met gebaren: hun hoofd, hun armen enz. spreken dan als het ware mee. Ze noemen die wijze van doen zelf mangopé-opé.

Meermalen bleek mij, dat zij een tegenzin hebben om des nachts in eeu kampong te overnachten, waarschijulijk uit vrees voor de booze geesten, die zij zich daar verzameld denken. Bij koude zitten

1 Wellicht ware het best dezen klank - in navolging van den heer C. A. van Ophuysen - door $b w$ weer te geven; eenvoudigheidshalve hebben wij daarvoor in dit opstel slechts $w$ gesehreven. 
ze gaarne om vuren; het gebruik van dekens is nog niet tot heu doorgedrongen.

In huis wordt de bijslaap niet geheim gehouden; in het enkele vertrek, waaruit de Loeboesche woning bestaat, slapen de kinderen met de andere huisgenooten bijeen.

Ze zijn onoprecht in dien zin, dat zij bij ontvangen bevelen op alles ja en amen zeggen, maar hun beloften ten slotte toch niet nakomen. De smalende uitdrukking pardjandjian Loeboe, die in het Mandailingsche en ook in het Maleische spraakgebruik zeer bekend is, karakteriseert bedoelde eigeuschap. Toch vormen de Loebve's een vreedzaam en lijdzaam volkje; misdrijven in koelen bloede gepleegd, komen bij hen zeldzaam voor. Maar de Mandailingers vreezen hen, omdat zij geacht worden met allerlei toovermiddelen (adji-adjian) vertrouwd te zijn, warmede zij anderen, tegen wie zij wraak koesteren, ouheilen kunnen berokkenen. Overigens worden de Loeboe's door den Mandailinger nog als minderwaardige schepselen veracht. Vermengingen van Loeboe's met Mandailingers komen daarom slechts hoogst zelden voor.

Daarbij komt dat de Loeboe van zijn kant zeer conservatief is en angstvallig gehecht aan zijn grond en zijn oude gewoonten, ook waar hij de meer beschaafde levenswijze van den Mandailinger leerde kennen. De zwaarste straf, die de Loeboe kent, is dan ook uit het adatverband gestooten te worden (dihasengkan-Mal. diasingkan).

Door die vasthoudendheid aan de traditie hunner oude zeden heeft de Islam bij de Loeboe's slechts langzaam ingang gevonden.

De Loeboe-vrouwen hebben een eigenaardigen gang, daarbij met de beide armen om en om naar de zijden slingerend (mangambè); de mannen loopen als regel min of meer gebogen. In tegenstelling met den Mandailinger, zit de Loeboe nooit met de beenen onder het lijf, maar steeds met opgetrokken knieën (manoenggang). Zij zijn zeer handig in het klimmen, zelfs vrouwen en kinderen klauteren als ratten in de hoogste boomen; dit is bijvoorbeeld het geval in den doeriantijd, van welke vruchten zij hartstochtelijke liefhebbers ziju. Klimmen zij tegen rechte gladde stammen op - bijv. iu klapperboomen - dan binden zij de voeten bij de enkels bijeen (singgobil). Zij ziju gerenommeerde klapperplukkers en verdienen als zoodanig vaak een ruim daggeld in de Mandailingsche klappertuinen.

In de keuze hunuer spijzen zijn de Loeboe's weinig kieskeurig; als een bijzondere delicatesse beschouwen ze het vleesch van muizen 
en vliegende honden; ook apenvleesch en wespenlarven gelden als lekkeruijen. In het algemeen kan men zeggen, dat alle soorten van vleesch, die de wildernis hun verschaft, door hen ook als spijs worden genuttigd. Kunnen zij het machtig worden, dan zijn ze ook nict af keerig van varkensvleesch; aan het houden van tamme varkens is echter door den invloed van den Islam een einde gemaakt. Toch zijn enkele vleeschsoorten voor de consumptie verboden, zóó b.v. de $S_{i}$ Baganding - een wormachtige slangensoort - en de Lompong Doeit - een zeer groote soort regenworm.

Vroeger was mais het hoofdvoedingsmiddel der Loeboe's, thans is ook de rijst bij hen een algemeen voedingsgewas, vaak met mais vermengd. Een typisch Loeboesch gerecht is loming, bestaande uit rauw fijngehakt vleesch, dat met allerlei kruiden in een bamboe wordt gekookt en als toespijs bij de rijst genuttigd. Een geliefd volksgerecht is nog gepofte mais gemengd met rauwe papaja-bladereu.

De Loeboe eet slechts eens per dag n.l. in den namiddag.

Vooral bij adatfeesten toonen zij zich groote liefhebbers van toewak (arenpalmwiju) die uit bamboekokers (jjanta) wordt gedronken. Ook zijn ze zeer verzot op tabakrooken en tabakpruimen (soegi-soegi). Dit laatste geschiedt zoowel door mannen als vrouwen. Het rooken van tabak geschiedt in den vorm van sigaretten, gerold in het schutblad van de mais of in nipahblad. Ontmoeten een paar Loeboe's elkaar, dan presenteert de een den ander zijn tabakdoos bij wijze van groet.

Toen A. P. Godon het bestuur in Groot Mandailing voerde - d. i. van 1850 tot 1857 — bestond de kleeding der Loeboe's, zooals hij beschrijft, slechts uit een stuk zacht geklopte schors van den toropboom om hun middel geslagen. Tegeuwoordig ziet men dit primitieve kleedingstuk niet meer. Alleen bij adatfeesten worden nog wel vlaggen van geklopte boomschors (tangki) rondgedragen en hebben de dragers bij die gelegenheden ook een soort shawl van die stof.

De gewone kleeding der mannen is een baadje en broek. Een eigenaardigheid is echter, dat zij hun baadje bijna nooit aanhebben, maar als regel in een kain gewikkeld over den schouder dragen. Zelfs als hij in den regen uitgaat, draagt de Loeboe zijn pakje op die wijze bij zich. ${ }^{1}$

1 Terwijl de Mandailinger zijn vrachten bij voorkeur op het hoofd draagt [mandjodjong], doet de Loeboe zulks liefst op den rug [mandokong]. Op den schouder dragen $=$ mamowsan $;$ aan de band dragen $=$ mandjèngdjèng $;$ onder den oksel dragen $=$ mangkopikopi $;$ een kind in een kain dragen $=$ mangombi . 
De vrouwen dragen bij wijze van saroeng een stuk doek om het lichaam, welke lap tot de knieën reikt; haar bovenlijf ongedekt latend.

In de keuze hunner kleedingstukken toonen de Loeboe's veel voorliefde voor helroode kleuren. Bij feesten dragen de vrouwen ook gaarne roode bloemen in het haar, dat zij in een losse wrong ( $\mathrm{sim}$ poeloet dalang) naar achter dragen, meestal bijeengehouden door de pen van eeu stekelvarken (goendjo) en welriekend gemaakt met de geurige bladeren van de apias - een parasiet, die tegen hoogstammig geboomte opklimt.

Eertijds makkten de Loeboe's een soort geurige haarolie uit benzoëhars (koemojan), voor welk doel thans algemeen klapperolie wordt gebruikt.

De ongehuwde vrouwen dragen halssnoeren (gondjong) en armbanden (sikandet) van groene, roode en zwarte kralen en verder oorringen (soebong) van zilver (pewak) of lood (simbowa).

Dat er bij een primitief oogenschijnlijk zoo prozaisch volkje als de Loeboe's nog zin voor poëzie kan schuilen, bewijzen hun oempama's of spreuken. Hiervan een paar voorbeelden.

$1^{\circ}$. Hoe inhoudvoller de rijsthalmen zijn, hoe meer ze zich buigen; zóó is het ook met ons menschen: hoe ouder en ervaringrijker wij worden, hoe nederiger wij moeten zijn. ${ }^{1}$

$2^{\circ}$. Men moet geen $\mathrm{kwaad}$ met $\mathrm{kwaad}$ vergelden: gooit men naar den manggaboom met steenen, hij werpt ons vruchten terug. ${ }^{2}$

$3^{\circ}$. Is men ruw tegen de meuschen, dan zal het ons niet voorspoedig gaan, is men minzaam jegens hen, dan zal het ook ons goedgaan. ${ }^{3}$

Ook hun raadsels (hoeling-koelingan) zijn soms aardig bedacht. "Wie maakt er veel lawaai, terwijl hij steenen verzamelt?" + Antwoord: de kip als ze eieren legt. "Hij die verbergt houdt zich stil, hij, die verborgen wordt maakt lawaai." ${ }^{5}$ Het antwoord is: het huis en zijn bewoner.

Het nationale wapen van den Loeboe is het blaasroer (oeltop). Dit

1 Hoebang nan toeho-toeho sapati podi nan masa pahotino, mailodo hoebang nan bahè, moelo moen mavisi moen matondo.

2 Batang monggo $i$ diwamban oewang dohot botoe diogihno boewono.

3 Djanglas kamotian, songko kahedopan.

4 Basoevak-soevak malonggokkan botoe.

5 Hanok namaündokan basoewak-soewak nadiandokan. 
bestaat uit twee holle, in elkaar geschoven bamboe's de buitenste van de bamboesoort boeloe sowik, de binnenste van boeloe prapat. Onderaan het wapen, dat ongeveer $2 \frac{1}{4} \mathrm{M}$. lang is, bevindt zich een moudstuk van karbouwehoorn en aan het tegenovergestelde uiteinde een dergelijk sluitstuk. Om te voorkomen, dat de binnenste bamboe schudt, wordt die omwonden met de vezels van den bast van den toropboom, welke vezels worden ingesmeerd met een soort gom, verkregen uit den bast van de batang sapot. De ongeveer 15 c.M. lange scherp aangepunte pijltjes (nangkat) zijn van een fijn gesneden bamboesoort (boeloe powing) gemaakt, aan het uiteinde warvan een stukje merg (widom) is aangebracht van galogariet (oenok galoga). Om den pijl beter in de ziel te doen aansluiten wordt onder tegen dat stukje merg bij het uitblazen van den pijl nog een stukje zwam (loeloek) gedrukt, af komstig van den arenpalm. Den noodigen voorraad pijltjes draagt men bij zich in een pijlenkoker (solpa); in het deksel waarvan de zwam is opgeborgen. De punten der pijltjes zijn besmeerd met een zeer krachtig gif, dat verkregen wordt door koking en indikking van de melksappen van bepaalde planten, waarvan de voornaamste zijn si topot wingwing, daboe imbo, silong doewah en silong mate. Heeft de pijl doelgetroffen, dan breekt de punt af. Het koken der bedoelde plantensappen geschiedt in de binnenste van een viertal bamboe's, die kokersgewijs om elkaar passen. Deze legt men eenvoudig in het vuur. Eerst brandt de buitenste bamboe weg, dan de volgende enz. Zijn er zóó drie van de bamboekokers weggebrand, dan rekent men het juist oogenblik gekomen, dat het gif voldoende is ingedikt. Deze handeling is niet ieders werk, maar het geheim van den dotoe of priester, tevens heksenmeester en bedicnaar der geneeskunde, daar er allerlei tooverformulieren bij te pas komen en tal van formaliteiten daarbij moeten worden in acht genomen. Vooreerst mag dit een en ander niet in huis gebeuren, maar moet het buiten in het bosch geschieden. Tal van personen staau den dotoe ter zijde en elk van hen heeft daarbij een bepaalde taak, in hoofdzaak bedoelende om de gewenschte uitwerkingen van het gif plastisch voor te stellen. Een klimt b.v. in een boom en laat zich quasi daaruit vallen, een ander doet of hij heftig moet vomeeren, weer een ander gaat naakt op den grond liggen en bootst stuiptrekkingen na enz. enz. Het gif is zeer werkzaam en wekt hevige brakingen op. ${ }^{1}$ Met het blaas-

1 Men beweert, dat wanneer een siamang in gezelschap van andere soortgelijke apen door dat pijlgif getroffen, neervalt en hevig begint te braken, 
roer weten de Loeboe's bijzonder handig om te gaau, van welke behendigheid de Mandailingsche tuinbezitters partij trekken door hen jacht te doen maken op de menigvuldige eekhorens, die hun klapperaanplantingen vernielen. Op ongeveer $50 \mathrm{M}$. afstand is de Loeboe tamelijk zeker van zijn schot, zelfs in hun vlucht weet hij de dieren juist te treffen. Tot in Rau bieden de Loeboe's hun diensten als eekhorenjagers aan en kunnen zoodoende eeu ruim daggeld verdienen, daar ze voor elk gedood dier tien cent ontvangen.

Behalve lansen (boebingan) dienen onder de wapenen voor het jachtbedrijf nog te worden genoemd het schietgeweer en het kapmes. Oude voorlaadgeweeren komen bij de Loeboe's tegenwoordig meer en meer in gebruik, ze koopen die voor ongeveer $f 5$ bij de Mandailingers. De monong en de sandong zijn soorten van kapmessen, die ook als wapens worden gebruikt; de badeh is een recht mesje, aan beide kanten scherp.

De muziekinstrumenten, die men bij de Loeboe's vindt, zijn zóó primitief, dat ze dien naam nauwelijks verdienen. Feesten komen bij hen weinig voor, de menschen zijn er te arm voor, en waar ze voorkomen, wordt daarbij nimmer muziek gemaakt. Verier zijn dansen bij bij hen oubekend, dus ook daarvoor is geen begeleidingsmuziek noodig. Daarom zijn hun muziekinstrumenten slechts beperkt tot eenige zeer eenvoudige speeltuigen tot begeleiding bij het voordragen van liedjes vooral bij lichte maan of als kortswijl waar men 's nachts om groote vuren bijeen zit te keuvelen: de Loeboe's toch zijn echte nachtbrakers. De gondang is bij hen niet als bij de Bataks een soort trom, maar een eenvoudige bamboegeleding, die als klankdoos dienst doet, waarbij een reep van de groene bast gedeeltelijk is opengespleten en door een soort kam gespannen, waarop met houtjes geslagen wordt. De otoek $\because \bigodot \begin{aligned} & \text { is eveneens een stuk bamboe, waarvan } \\ & \text { men tot zekeren afstand aan weers- }\end{aligned}$ zijden een stuk uitkapt en waarlusschen dan met een stokje. getokkeld wordt. Verder weet men nog heel aardig te toeteren op een soort bamboefluitjes (toelila).

In de stilte van den nacht houdt men ook van het zangerig opdreunen van dichterlijke improvisatiën '[èndè-èndè] die men met

de andere apon dan direct afdalen en van het braaksel meêeten, waardoor in weinig tijd de heele kolonie, de een na den ander onder sterke krampverschijnselen bezwijkt. 
de Maleische pantoen's kan vergelijken en waaraan zoowel mannen als vrouwen deelnemèn.

Aan het z.g. toeri d.i. het reciteeren van verhalen door oude lieden, gepaard met het drinken van toewak, wordt alleen door mannen deelgenomen. In die verhaleu spelen de heldennamen van Soetan Naposo Dilangit, Toeankoe Malim Deman, Si Moget Daoewano, Soetan Bagindo en Si Tapi Gondom Baroes een groote rol.

\section{Bestuur. Volksindeeling. Woningen.}

De Loeboe's wonen in verspreid staande hutten. Een groep van zulke hutten vormt e€n nederzetting [bandja]. Het aantal nederzettingen bedragt thans elf, over de Mandailingsche districten [koeria's] Kota Siantar, Goenoeng Baringin en Goenoeng Toewah verdeeld. Het hoofd van zulk een bandja heet na-bodjo bodjo of in navolging van de betiteling der op de laagste bestuurssport stande Maudailingsche volkshoofden ook wel kapala ripé. Terwijl echter de Mandailingsche ripéhoofden als regel onder een kampoenghoofd staan, is dit bij de Loeboesche ripéhoofden uitzondering: in de meeste gevallen staan dezen onder het direct gezag van het betrokken districtshoofd. Alleen in de nederzettingen Sopo Batoe en Si Ladang staat liet ripéhoofd onder een kapala kampoeng. Dit kampoenghoofd noemen zij toean diwi d. i. onze heer. (Maleisch: toean diri); volgen ze de directe bevelen van het districtshoofd, dan is deze hun toean diwi. Een vrouw van een na-bodjo bodjo voert den titel van nan kojo. De familiehoofden of oudsten, die als raadslieden een aandeel hebben in het bestuur heeten nan toeho-toeho. De waardigheid dier hoofden is erfelijk: bij verkiezing van een nieuw hoofd komt de oudste zoon van den laatsten titularis het eerst in aanmerking naar den regel: hèlang waoet bosèlèh monong d.i. in het Maleisch: ilang raoet berganti parang. Van een adelstand als in Mandailing is bij de Loeboe's geen sprake.

Evenals de Mandailingers zijn ook de Loeboe's in marga's verdeeld. Bij de Loeboe's in Kota Siantar treft men de stamnamen Loebis en Djamboe aan, in Goenoeng Baringin de namen Parindoeri, Gorotan en Batoe Barah, terwijl in de koeria Goenoeng Toewah de stamnaam Nasoetion sterk overwegend is. Deze zelfde marganamen vindt men ook bij de Mandailingers terug.

Volgens getuigenissen der ouden zouden de Loeboe's vroeger hunne hutten in boomen hebben gebouwd. Thans treft men die boom- 
woningen nergens meer aan. De meeste hunner armzalige hutjes [awatak = Bat. aratak $]$, die hun tot behuizing strekken, staan direct op den grond. De Loeboe slaapt bij voorkeur op den grond, zelfs waar hem de keuze van een betere ligplaats gelaten wordt. De grootere op palen gebouwde woningen heeten oemo. Onder die palen is dan een hok voor de geiten en het pluimvee.

Al die woningen en haar omgeving zijn intens vuil: daar men zijn behoeften in huis doet en alle afval door het raam een uitweg vindt, worden die woonsteden tot drassige poelen en verzamelplaatsen van allerlei ongerechtigheden, waarin kippen en honden rondwroeten in de hoop er nog iets naar hun gading in te vinden. In die huizen is het door den stank voor vreemden dan ook niet uit te houden, vooral des avonds niet, wanneer het damarlicht zijn walmen met de overige geuren vermengt.

Gaat de Loeboe een Mandailingsche kampoeng bezoeken, dan zegt hij, dat hij naar de doson gaat.

Rijstschuren kent hij niet: zijn rijst bewaart hij in huis in zakken van boomschors (tangkiding).

Hun hutten bestaan uit slechts één vertrek en ziju-van eenvoudig ruw hout of bamboe opgetrokken en ingedekt met de bladeren van de padang (d. i. ilalang) of van den salakpalm.

\section{iII. Familieleven. Geboorte. Huwelijk. Lijkbezorging.}

\section{ERfrecht.}

Ook naar de begrippen der Loeboe's is het uitblijven der menstruatie - zij noemen dit "de maan niet meer zien" - het zekere teeken, dat de zwangerschap is ingetreden. Om den duur dezer periode te volgen, brengt men tegen den huiswand een krijtstreep an en teekent er verder iedere maand een streep bij. Is de graviditeit drie maanden gevorderd, dau moet de vrouw tot op het oogenblik harer bevalling [sobang] dagelijks een soort aarde eten, die bangè heet, naar men zegt, om brakingen te voorkomen.

Heeft de zwangere (bontèng) zeven maanden "gedragen" (mangkondoeng-kondoeng), dan wordt een oude vroedvrouw (dotoe) geroepen en aan haar verder de zorg voor de a.s. moeder toevertrouwd. Door tasten en voelen van den buik stelt zij een uitwendig onderzoek in naar de ligging van de vrucht. Wordt een ongunstige positie (tasobol) geconstateerd, dan tracht de dotoe door massage (mangoboet) het kind de gewenschte ligging te geven.

Met de negende maand wordt de vrucht geacht voldragen te zijn, 
een vroeggeborene van zeven maanden heeft, naar men meent, nog goede levenskansen, maar die kansen worden minder als het kind met de achtste maand het leven ziet. Een ontijdige geboorte (d. i. biunen de zeven manden) heet namolas.

Daar men zeer bang is, dat een foetus in handen komt van kwaadwilligen, wordt dit steeds in alle stilte 's nachts begraven nabij de wortels van een melksap bevatteuden boom, in de meening dat dit foetuslijkje - dat de moedermelk moest ontbereu - uit die wortels de melk zal kunnen opzuigen.

Merkt de vrouw, dat de bevalling anstaande is, dan legt ze zich achterover op een matje neer, terwijl ze de knieën opgetrokken houdt; de vroedvrouw begint haar onderlijf te masseeren. De.patiënte heeft voorts te zorgen, dat ze in dezelfde richting ligt als de nok van het dak, daar de bevalling anders zou worden vertraagd.

Zijn de dolores ad partum ingetreden, dan spant men aan de zoldering een afhangend touw van boomschors, dat de barende met beide handen beetvat. Deze rust op de knieën met de beenen wijd uiteen, terwijl haar man haar van achter onder de armen ondersteunt.

De vrouw wordt nu een drank toegediend, bereid uit de in water uitgeperste takjes van stinkende planten, vermengd met een fijngestooteu eierschaal, die reeds door een kuiken is opengebroken. Die kwalijk riekende planten hebben de bedoeling om booze geesten, die de barende in deze gewichtige oogenblikken zouden willen belagen, af te schrikken; van de eierschaal hoopt men eene sympathetische werking в.l. dat zij het verwachte kind zal aansporen om even vlot uit zijn schuilhoek te roorschijn te komen, als het kuiken uit die eierschaal kwam.

Vooral de rondspokende, naijverige zielen van in het kraambed overleden vrouwen hebben het op de a.s. moeder voorzien. On er tegen te waken, dat deze door die kwaadwillige geesten bezeten (tatomos) zou worden, braudt men in hare nabijheid allerlei prikkelende en walgelijk riekende stoffen zooals zwavel, karbouwehoorns enz.

Loopt de partus niet vlug af en zijn er kunstbewerkingen noodig, dan wordt een mannelijke dotoe geroepen. Is de nood op het hoogst, dau brengt hij de hand in de vagina om het kind zoodoende te extraheeren. Meestal heeft hij vooraf een ander meer onschuldig obstetrisch middel - saloesoe (Mal. seloesoeh) genaamd - te baat genomen om het kind te voorschijn te roepen, dáárin bestaande, dat hij een stuk van een bamboegeleding, die met water is gevuld, waarover vooraf een tooverformulier is uitgesproken, met kracht 
tegen den grond werpt, in de hoop, dat het kind door den slag zal schrikken en daardoor naar buiten zal komen.

Men moet er vooral voor oppassen, dat niemand tijdens de bevalling om den hoek van de huisdeur kijkt, anders zou de kleine in navolging daarvan misschien ook den verkeersweg stremmen en zoodoende de verlossing vertragen. Om dezelfde reden. moeten binnenkomenden en uitgaanden ook doorloopen en niet aan den drempel blijven staan. Alle kisten en kasten moeten openstaan en de kleederen en het haar van de vrouw moeten loshangen. Verder zal men alle moeite doen een kip te zoeken, die op haar eieren broedt (sa kapah na modomkon) en die vóór de barende neerzetten, door welk aanstekelijk voorbeeld de bevalling zeker zal worden bespoedigd. Men moet zorgen, dat de vrouw niet door vermoeienis in slaap valt, anders zou ze in haar droomen misschien andere gedachten krijgen, hetgeen een onvoorspoedige bevalling zou provoceeren.

Is de nieuwe wereldburger eindelijk verschenen, dan bindt de dotoe de navelstreng (toli poesot) met een draad af en snijdt haar door met een scherp stukje bamboebast (sambiloe) op de plaats waar ze op een stukje curcuma (konjèh) rust. Is de funiculus afgevallen, dan wordt het in een stukje goed genaaid en zorgvuldig weggeborgen, opdat kwaadwilligen er geen misbruik van zullen maken.

De nageboorte (odik) wordt, na met water te zijn gewasschen, in een nieuwe rijstpot gedaan, die met een witte kain wordt gesloten en daarna onder het huis begraven, terwijl een steen op het grafje de plek aanduidt. Huilt het kind later veel, dan schrijft men dit daaraan toe, dat mieren in den begraven rijstpot zijn gekomen en de nageboorte steken. Vandaar dat men in dat geval heet water op het grafje uitstort om de mieren te verdrijven.

Nadat men het kind met warm water heeft gewasschen en daarna in een ouden vuilen doek (koin bobo) heeft gewikkeld, krijgt de moeder een beurt. Haar buik wordt vrij krachtig met een wiudsel ingesnoerd, om latere afzakking te voorkomen; gedurende zeven dagen moet dat suoer blijven zitten en mag zelfs bij het baden (mondi) niet worden afgelegd. Verder moet zij zeven dagen lang dag en nacht met haar kind op een rustbank (pawapian =- Bat. parapian vg. diapi) liggen, waaronder een zacht smeulend vuurtje blijft branden. Gedurende dien tijd moet ze ook drie maal daags met uitgespreide beenen boven een grooten pot staan, waarin bladeren van den cassia florida (bolong djio = Bat. boeloeng ni djior, Mal. daoen djoear) worden gebrand. Deze beide roosterkuren hebben, naar 
men zegt, de bedoeling een uitdrogende werking op de lichaamssecreties.

Een kind met het helmvlies (tampowong) geboren, gaat voor een gelukskind (onok batoewo) door, het zal later niet alleen onkwetsbaar (kobo) wezen, maar alle mogelijk geluk zal zijn deel zijn.

Vóór de zuigeling aan de borst der moeder wordt gelegd, wordt hij even met de lippen tegen een der borsttepels van den vader gedrukt, bij een jongen rechts, bij een meisje links. Dit gebeurt, naar men mij mededeelde, opdat het kind later geen spruw of diphteritus (goeam) zal krijgen.

Als de zogtoevloed niet wil komen bij de vrouw, dan geeft men haar gegiste palmwijn (soeri) te drinken en als dit niet voldoende helpt, prikt de dotoe voorzichtig met een naald in de tepels der vrouw, welke operatie men panggadoe noemt. Is er wèl zog, maar is het kind afkeerig om te zuigen, dan schrijft men zulks daaraan toe, dat de rondspokende ziel van een onvoldragen foetus het zulks belet. Die ziel, die dus steeds de moedermelk heeft ontbeerd, is namelijk naijverig op den jonggeborene en wil hem daarom van het zuigen afhouden. Om die naijverige ziel te bevredigen, neemt me!ı daarom het volgende kuustje te bat. De dotoe neemt ee! rijstwan (panompi), legt daar allerlei heerlijkheden op zooals zout (si mosin), gember (pégé), visch, jong pisangblad, een paar rijstbolletjes enz., en houdt dat vóór de borsten der vrouw, zeggende: "hier is ander voedsel in ruil" (pahaséléh) d.w.z. in ruil van de moedermelk. Men hoopt, dat het kind nu rustig zal gaan drinken. Heeft de moeder heel geen zog, dan legt men het kind ook wel aan de borst van een andere vrouw, hetgeen men mananggil (v.g. Mal. manompang) noemt.

Het is een gunstig teeken als het kind overdag wordt geboren, daar ook zijn verstand dan later meer "verlicht" zal zijn. Het beste tijdstip is 's middags om 12 uur bij hoogsten zonnestand.

Het aantal bevallingen van een vrouw kan men gemiddeld op vijf stellen. Meervoudige geboorten heeten lindoeat, drie- en meerlingen zijn echter zeldzaam. Doodgeboorten - die veel voorkomen noemt men tingga di talogo d.w.z. "achter gebleven in het voorhuis".

Geboorten buiten huwelijk ziju zeldzaam, de Loeboe beschouwt die als een schande. Een buiten huwelijk geboren kind heet gampong; spottenderwijs noemt men zoo'n kind ook wel poeloengan (vg. Mal. ramoean) d. w. z. "een mengelmoes" (van meer vaders). Ook vruchtafdrijving (mangalobo) komt weinig voor. Onverınogen tot bevruchting 
is bij mannen frequent, terwijl steriliteit bij vrouwen zeldzaam zou zijo. Impotentie bij maunen noemt de Loeboe: hando so hojoe d.i. "noch liaan noch boom", wij zouden zeggen noch vleesch uoch visch.

Gedurende de eerste zeven dagen en nachten na de bevalling wordt door de vrouwelijke verwanten om beurten bij moeder en kind gewaakt. De familieleden komen spoedig door kraamvisites van hun belangstelling blijk geven en nemen dan, schotels met rijst mee, op elk waarvan een gepeld kippenei (ambolo si kapah).

Daar de jeugdige spruit in zijn eerste levensperiode - naar het volksgeloof - aau allerlei noodlottige invloeden van kwade geesten blootstaat, moet men er steeds voor zorgen door loftuitingen als anderszins de aandacht dier booze geesten niet te veel op den jongeu kleuter te vestigen, daar deze daar zeker de nadeelige gevolgen van zou ondervinden. Men moet b.v. vermijden te zeggen, dat hij dik of gezond of mooi is, liever zegge mon het tegenovergestelde n.l. dat hij mager, of leelijk is. Ook wachte men zich, om de zelfde reden, te zeggen, dat het kind b.v. zes of zeven dagen oud is, want dan zou het zeker gauw sterven, men zegge dan — ook weer om de naijverige geesten te misleiden - dat het zes of zeven jaar is.

Bij de geboorte van een kind is het gebruikelijk, dat de ouders een grooten haan in huis nemen, die omban ni tondi wordt genoemd d.i. vasthouder van de ziel (van het kind). Is de dreumes in zijn eerste levensdagen ziek, dan baadt men dien haan en wascht het kind met het gebruikte badwater.

Is het wicht twintig dagen oud, dan wordt het met eenige plechtigheid voor de eerste maal gebaad (memondikan si boedak). Als het daartoe de huistrap wordt afgedragen, heeft men het om de polsjes armbauden aangedaan van een grassoort die padaing togoe heet. Dit woord togoe beteekent "krachtig" en door dien naam hoopt men dat die armbanden de ziel van het kind ook krachtig zullen maken. Beneden aan de trap, waar de familieleden bijeen ziju, wordt het kind dan door een der oudsten gebaad. Hierbij worden oude lappen (damoean) verbrand, om door den stank kwadwillende machten op een afstand te houden (tangkal hontoe). Vervolgens brengt men het kind weer in huis en schommelt het in een stuk goed, dat aan beide uiteinden bij wijze van hangmat is vastgebonden. Bij dit heen en weer wiegen kijkt men goed toe, hoe het kiud doet, omdat men hieruit gevolgtrekkingen maakt voor zijn verder leven. Ligt het rustig te lachen, dan zal veel levensgeluk 
zijn deel ziju, doet het dan echter een kleine commissie, dan is dit een slecht teekeu en zoo meer.

Daarua wordt de bovenbedoelde gelukshaan geslacht, in ziju geheel gepoft en op een bord rijst neergelegd. Dit een eu ander wordt boven het hoofd van het kind gehouden, dat nu zijn eersten naam (gala kaljik of gala Si Boedak) ontvangt. Over de keuze van dien nam is te voren uitvoerig door de oudste verwanten beraadslaagd. Zijn er tweelingen, dan is het gebruikelijk bijna gelijkluidende namen voor hen uit te kiezen, heet de ees b.v. Si Tomet, dan wordt de audere $S i$ Sobel genoemd enz. Meisjesuamen zijn o.n. Si Sosak (de huishagedis), Si Lambok (de zachte), Si Lamasél (vischnaam) etc. De moeder spreekt men aan bij den naam van haar eerste kind b.v. Amai Sosal en deze noemt haar man ook naar zijn eerste kind b.v. Bopo Sosak.

Gelijktijdig met de naamgeving wordt het kind voor de eerste maal het haar geknipt. Ook deze operatie gaat met eevige plechtigheid gepaard. Zij geschiedt door den grootvader (uénék) van het kind, of door iemand die in familieraug met hem gelijkstaat. Men mag hierbij echter het woord "haarknippen" niet gebruiken, daar anders de opmerkzaamheid der omringende geesten zou worden opgewekt, men spreekt dan in tegenovergestelden zin vau het "verlengen van het haar" (bapandjang habo). Het eerst geknipte haar wordt met het afgevallen navelstrengetje zorgvuldig bewaard. Na de haarsnijding bij een jongen blijft vóór op het hoofdje één vlok (djoembik) staan, bij een meisje twee vlokken (gontjé) bij de slapen.

Heeft men reeds eenige zoons en bestaat het verlangen naar een dochter, dan gebeurt het vaak, dat men zijn jongens als meisjes kleedt, hun een halsketting omhangt en hen als meisjes knipt. Het omgekeerde komt eveueens voor, als de ouders rijk van dochters gezegend zijn en naar een stamhouder verlangen. Men noemt deze wijze van doen sintò-sintò (vg. Mal. berrtjinta).

Totdat zij ongeveer 12 jaar oud zijn, worden de meisjes meestal toing en de jongens dalikan genoemd. Hef kind krijgt de borst, totdat de moeder opnieuw zwanger is, anders twee tot drie jaren lang. Zijn de meisjes ongeveer twee maanden oud, dan worden haar oorlellen doorboord (manoewa = Bat. toera).

Tot hun vierde jaar loopen de kleuters in het kleed der onschuld rond, alleen drageu zij van achter of om den hals een snoer, waaraan de een of andere amulet (tangkal). Een veel voorkomende amulet is b.v. de si palis d.i. een stukje van een klimparasiet van dien 
naam, welke naam "mis", "niet geraakt" beteekent, men hoopt daardoor dat allerlei ziekten op het kind geen vat zullen hebben.

De zorg voor de kinderen is zoowat nihil. Gaan de vrouwen de ladang's bewerken, dan worden de kinderen allen meegebracht. De zuigelirgen worden dan eenvoudig zonder eenige beschutting tegen zon of regen in een doek gedeponeerd, dien men middels twee in den grond geplante stokken tot een soort hangmatje heeft gemaakt en waariu men de schreeuwende kleinen kalm aan hun lot overlaat. Toch verbaast men er zich over, dat kinderziekten bij de Loeboe's betrekkelijk zeldzaam zijn.

Slechts zeer weinig kinderen volgen het Mohammedaansche godsdienstonderwijs, ook laten de Loeboe's hun kinderen niet de Gouvernementsscholen bezoeken. Naar de reden hiervan vragende, kreeg ik tot antwoord, dat ze vreezen, dat hun kinderen, wanneer dezen het onderwijs hebben gevolgd, in Gouvernementsdienst later zullen overgaan en dan naar streken ver van vriend en magen zullen worden overgeplaatst.

De besnijdenis (totak) wordt weinig toegepast; bij meisjes wordt de operatie nooit uitgevoerd en waar ze bij jongens wèl voorkomt is de eenvoudige splijting gebruikelijk en wordt ze door een leek verricht. Vaak geeft deze operatie dan ook aanleiding tot hevige ontstekingen.

Vóór haar huwelijk worden bij de meeste meisjes de tanden gevijld (maämbéh ipon) en daarua zwart gemaakt (mambodjo ipon), door ze geruimen tijd achtereen te bestrijken met koolzwart, dat men verkrijgt door eenige droge citrus-takjes te branden en den walm te laten strijken tegen een mes. Het vijlen der tauden geschiedt door een z.g. tokang ipon. Bij mannen komt deze bewerking veel minder voor.

Zoodra zij den leeftijd hebben bereikt, waarop ze de aandacht der sterke sexe op zich gaan vestigen, zijn de Loeboesche meisjes zeer op allerlei sieraden gesteld, zooals halssnoeren (gondjong) en armbanden (sikandet) van groene, roode en zwarte kralen, ook oorriugen (soebong) van zilver (pewak) of lood (simbowa).

De adat maakt het vrije verkeer tusschen de jongelieden van beiderlei kunne zeer gemakkelijk. Zijn de jongens ongeveer twaalf jaar oud, dan brengeu zij de nachten niet meer bij hun ouders door, maar in een afzonderlijke woning, die tawatak heet. Ook de meisjes van dien leeftijd komen tot op het oogenblik van haar huwelijk des avonds in een tawatak bijeen, waar ze onder de hoede 
zijn van een oude weduwe, en waar ze ook den nacht passeeren. Des avonds tegen zeven uur - d.i. na den maltijd - gaan de meisjes er heen en keeren 's morgens om zes uur weer naar haar ouderlijke woning terug. Maar behalve de slaapplaats der huwbare meisjes is de tawatak tevens de plats voor de gezellige bijeenkomsten (mamajam) der jongelui. Heeft de oude vrouw het damarlicht in huis ontstoken, dan flaneeren de jongens daar reeds voorbij. "Nénék, mogen we binnenkomen?" "Kom gerust", zegt het oudje. De jongens zetten zich op een matje op den vloer bij de dorpsschoonen neer. De walmende damarpit verlicht het vertrek flauwtjes. De oude matrone heeft de sirih met toebehooren al klaargezet. De meisjes deelen de pruimpjes uit. Is de eerste schroom overwonnen, dan wordt er over en weer gegekscheerd en het gesprek met allerlei toespelingen z.g. kié (vg. kïás) gekruid. Heeft een der jongens (boedjing) een pruimpje ontvangen, dan zal hij, zonder het nog geproefd te hebben, b.v. ondeugend zeggen: "hè, wat smaakt dat lekker, en wat is het keurig dichtgevouwen". - "Och", zegt dau de toegesprokene, "wees maar niet zoo galant, men kan toch geen olie met water mengen". Ze drukt zich met deze woordspeling zeer bescheiden uit, want ze waarschuwt daarmede haar vriend, dat hij maar niet te veel toenadering moet zoeken, hij zal toch niets van haar moeten hebben, daar ze zijn gelijke niet is. Zóó lokt ze een nieuw compliment van haar bewonderaar uit, want deze laat er hoffelijk op volgen: "wat ben je nederig, maar dat is niet noodig, hoor, de vrucht vau de sabiplant is al fijn van zich zelf, ook zonder dat die gemalen wordt". Het meisje is er blijkbaar mee gevleid, want ze gaat voort: "ik begrijp je heel yoed, al spreek je niet ronduit, ook de glazenmaker (siwi-siwi $=$ Bat. siri-siri) ziet heel goed, al is er geen pupil in zijn oogen". Zóó komt men van keuvelen tot kozen, en ook dit laatste laat de adat toe, mits - in alle eer en deugd. Trouwens de nénék heeft levenservaring genoeg, om te begrijpen, wanneer een wenk tot vertrek van de galante ridders noodig is; want hebben de vrijages wat lang geduurd, of wordt de vertrouwelijkheid wat al te groot, dan voegt ze hun toe: "ga nu maar weer heen, jelui doet net als de danau-vogel, geeft men $u$ een vinger, dan neemt ge de heele hand" (dibawikan sadjangka na sadapa). Om deze woordspeling te begrijpen, moet men weten, dat de danau van kleine vischjes leeft; een eigenaardigheid van dezen vogel nu is, dat als hij eenmaal een vischje te pakken heeft gekregen, hij uren lang op dezelfde plaats aan Dl. 66 . 
den waterkant blijft staan, tot dat hij daar op nieuw een prooi vindt.

Er dient nog vermeld, dat zulke vrijages als bovenbedoeld alleen zijn toegelaten onder jongelui van verschillende marga. Maar ook buiten het mamajam staan den jongelui allerlei wegen open om hun gevoelens jegens elkander kenbaar te maken. Meestal gaan deze keunismakingen aau het mamajam vooraf. Heeft b.v. bij een meisje het minnend hart gesproken, dan kan ze hiervan blijk geven door haar beminde in het geheim - buiten medeweten der ouders - haar slendang toe te zenden, waarin een sirihpruim, een geldstuk en verder allerlei plantjes zijn gewikkeld, die alle een symbolische beteekenis hebbeu. Is de genegenheid wederkeerig, dan aanvaardt hij dit geschenk en zendt haar daarna de slendang met het geldstuk terug met wat tabak (timbako) en nipahblad (potjo) en eenige plantjes, in welker naam hij zinnebeeldig zijn gezindheid jegens zijn geliefde vertolkt. Zóó zendt hij haar b.v. een grassoort, die tomo djalan (= op den weg ontmoeten) heet, waarmede hij het meisje stilzwijgend uitnoodigt tot een vertrouwelijke samenkomst buiten. Wil hij haar echter een blauwtje laten loopen, dan zendt hij b.v. cenige takjes van de baleh sompah (vg. Mal. balik soempah) d. i. "van belofte veranderen" of wel een haantjesduit (gentjeh), omdat tagolentjeh "slippen", "uitglijden" en in afgeleide beteekenis "afwijzen" "een blauwtje doen loopen" beteekent.

$\mathrm{Na}$ de beschreven vrijages is de verloving de eerste stap tot het huwelijk. De meeste meisjes huwen op ongeveer 15jarigen leeftijd. Ze zouden het een schande vinden als oude vrijsters te moeten blijven zitten, de menschen zouden dan van haar zeggeu, dat ze zijn als de vruchten van het bamboe, die, als ze in het water vallen, niet door de visschen worden gegeten en als ze op het land vallen, niet door de kippen worden weggepikt. Huwelijken op zeer jeugdigen leeftijd - die in Mandailing zóó frequent zijn-komen echter bij de Loeboe's niet voor: "men krijgt geen goed gewas" - zoo drukken zij zich uit - "als men de klappervruchten te jong uitplant".

Alvorens na te gaan hoe het Loeboesche huwelijk tot stand komt, dient nog opgemerkt, dat bij de Loeboe's evenals bij de Bataks uitsluitend het patriarchale huwelijk in zwang is: de vrouw volgt den man, de kinderen behooren tot den stam van den vader en de afstamming volgt alleen de mannelijke lijn. Echtverbintenissen tusschen personen van dezelfde marga zijn verboden en worden als bloed- 
schande beschouwd (sombang). In vroegeren tijd moest in zoo'n geval de schuldige man een varken slachten voor een offermaaltijd aan zijn kamponggenooten, een zwarten haan loslaten en verder een geweer afschieten als zinnebeedig teeken, dat hij zijn marga als het ware had weggeschoten: "paäbang boeloeng" (vg. Mal. mĕnĕrbanglian daoen).

De verloving (matandatanda) duurt gewoonlijk twee volle jaren. Die jaren zijn voor den huwelijkspretendent een zware proeftijd, daar hij dan voor zijn aanstaande schoonouders allerlei zware diensten (pakadjä̈n) moet verrichten. Zelfs na de echtverbintenis legt de adat den jongen man allerlei verplichtingen met betrekking tot den veldbouw ten behoeve van zijn schoonouders op. Deze verplichtingen noemt men gogo na moehoet d. w. z. "allerlei werk". Daar tegenover stat dat de bruidschat (djodjowan = Bat. djoedjoeran) zeer laag is n.l. 300 piti's (f 2.50) — terwijl in Mandailing voor een vrouw uit de volksklasse ruim twintig maal zooveel wordt betaald.

De bedoelde staat van dienstbaarheid waarin de jonge man tegenover zijn a.s. schoonouders komt te verkeeren is in zekere mate een waarborg, dat de Loeboe niet zoo lichtvaardig een huwelijk sluit als de Mandailinger. Men kan dan ook als regel zeggen, dat bij de Loeboe's de verbintenissen uit wederkeerige genegenheid der jongelui gesloten worden en dat de wenschen der wederzijdsche betrekkingen daarbij van ondergeschikt belang zijn.

De adat wil, dat men bij voorkeur huwt met zijn bowoe toebang (Mandel. boroe toelang; boroe $=$ dochter, toelang $=$ moeders broeder) d. i. met een dochter van den oom van moederszijde. De formaliteiten voor zoo'n huwelijk zijn zeer gering. Men beschouwt zulk een verbintenis als van zelf sprekend en zegt er van: hatjai togolong ka bebeng d.i. de bloedzuiger rolt naar de open wond en men bedoelt er mee, dat het genoemde dier gemakkelijk zuigen heeft nabij de wond, immers het bloed stroomt het dan vanzelf te gemoet.

Vóórdat tot het huwelijk wordt overgegaan wordt daartoe door den dotoe een gunstige dag (howi nan saè) vastgesteld, waartoe hij zijn wicheltafel (pakalakalahan) raadpleegt d. i. een bamboe, waarop allerlei figuren zijn gegrift.

Drie dageu vóór de eigenlijke huwelijksvoltrekking wordt een feestmaaltijd aangericht ten huize van het meisje, waarbij ook de jonge man en diens verwanten (behalve zijn ouders) aanzitten. Bij deze gelegenheid draagt de vader op plechtige wijze zijn dochter aan haar aaustaande over. 
Daarna gaat men in feestelijken optocht (mawoedoeb) naar de woning van de ouders van den bruidegom: een oude vrouw loopt in zeer langzaam tempo voorop en de vrienden en verwanteu volgeu voetje voor voetje. Bij de woning van den bruidegom aangekomen, vat diens moeder de bruid bij de hand en voert haar de woning harer schoonouders binnen. Ook hier beeft een maaltijd plaats, waarop de bruidegom naar zijn nieuwe woning gaat, terwijl de bruid in het huis harer a.s. schoonouders achterblijft.

Drie dagen later is de dag van de eigenlijke huwelijksvoltrekking de z.g. howi makawoan (vg. Mandel. hari markaroan). Er heeft dan een eenvoudig bruiloftsfeest plaats, waarvan een maaltijd weer de hoofdzaak is en waarbij allerlei ceremoniën plaats hebben, doelende op een bezegeling van den huwelijksband, met welke ceremoniën het huwelijk geacht wordt voltrokken te zijn. Het plechtigste moment hierbij is, dat de bruidegom zijn bruid van hare sieraden ontdoet; de adat toch laat aan gehuwde vrouwen het dragen van sieraden niet toe. Deze plechtigheid heet namabodjoe-bodjoe, door dien naam er op zinspelende, dat de vrouw alleen haar baadje nog overblijft. Zij verliest op dat oogenblik haar naam en blijft namabodjoe heeten, tot de geboorte van haar eerste kind, alsdan wordt ze naar dat kind genoemd. De jonggetrouwden eten op het feestmaal gezamenlijk fijne gepofte zaden van de longaplant, welke met een gepeld kippenei op een schotel worden opgediend. De bedoeling is, dat het gewenschte kroost uit dezen echt even talrijk moge ziju als die zaden. Verder moet de bruid in een bamboekoker water halen, terwijl ze daarbij een klein kind draagt, het eerste als zinnebeeld harer verplichtingen als huisvrouw, het laatste met de bedoeling, dat ze spoedig zulk een kind moge ter wereld brengen.

Terwijl de jonge vrouw op dezen dag - zooals gezegd - haar naam verliest, krijgt haar echtvriend dan juist een nieuwen naam (gala hawodjoan = Bat. haradjaau). Die nieuwe uaam houdt altijd verband met den naam, dien de betrokkene als kind gedragen heeft (gala si-boedak). Heeft hij b.v. als kind Si Babi geheeten, dan worlt zijn nieuwe gala: Bawagus (d. i. zwijn, Bat. baragas); heette hij Si Tombang (de gouddelver), dan is b.v. een passende gala: Dja Paloeangan (de goudwasscher), bij Si Mokmok (de dikke) behoort Dja Manggidoer (de vette), bij Si Tawoboes (de fez) past Dja Kopiah (de muts) enz.

Op het bruiloftsfeest mogen noch de vader van de bruid, noch zijn margagenooten tegen woordig zijn. 
Is de voltrekking van het huwelijk afgeloopen, dan gaan de jonggehuwden nog niet direct naar hun eigen woning; de adat schrijft uitdrukkelijk voor, dat zij eerst gedurende zeven dagen in afzondering (woboe $=$ Bat. roboe) moeten doorbrengen in het huis der ouders van den man, die dan op hun beurt in de woning der jongelui trekken. Eerst na afloop van dien termijn mag het jonge paar in eigen woning gaan. Dit heet paloewas woboe (vg. mĕlëpaskan pantang). Het huis der ouders beschouwt men de verzamelplaats te zijn der tondi's van het gezin (pakompolan tondi), daarom wil de adat - zooals mij werd medegedeeld -- dat het jonge paar daar ook eenigen tijd heeft doorgebracht, voor het zijn eigen domicilie betreedt.

Het huwelijk bij schaking (manangko) — dat in Mandailing zoo vaak voorkomt met de bedoeling de omslachtige en veel tijd en geld roovende formaliteiten te ontgaan - is bij de Loeboe's niet toegelaten.

Een andere huwelijksvorm, die even als in Mandailing ook bij de Loeboe's voorkomt is het z.g. manjompo (het grondwoord sompo beteekent "onverwacht verschijnen"). Hoewel de adat deze wijze van huwelijksluiting strikt genomen niet regelt, wordt zij toch niet alleen getolereerd, maar komt zij vooral bij de Mandailingers dikwijls voor omdat zij weinig omslachtig is en in dit geval geen bruidschat verschuldigd is. Het meisje dringt zich hierbij 's avonds onopgemerkt en onverwacht de woning der ouders van den jongen man binnen - vaak door haar vader daartoe aangezet - voorgevende, dat zij het al lang met haar uitverkorene eens is, dat zij met hem in het huwelijk wenscht te treden en dat zij, indien haar daartoe geen toestemming wordt gegeven, het huis niet wil verlaten. Soms leidt dit tot een gunstig resultaat tusschen de wederzijdsche verwanten, maar wordt geen overeenstemming verkregen, dan zijn de meest hartstochtelijke scènes hiervan vaak het gevolg. Ook waar een meisje al te intiemen omgang met haar minnaar heeft gehad en de onloochenbare teekenen hiervan zijn aan den dag getreden, wordt het manjompo toegepast als redmiddel harer eer. In dit geval geeft het steeds aanleiding tot heftige tooneelen, daar de huisbewoners dan al het mogelijke zullen doen om de brute indringster des noods met geweld hun huis uit te jagen. Naar het volksgeloof toch wil, brengt zwangerschap buiten echt de jonge vrouw in den toestand van loö̈ (Mandel. rö̈r) d.w. z. dat ze overal ongeluk verspreidt, waar ze komt. 
Ook het z.g. leviratshuwelijk (mangabiah) is bij de Loeboe's in zwang. Als regel wordt de weduwe (bawando) door een jougeren broeder van haar overleden man tot vrouw genomen. De adat schrijft voor, dat die broeder zijn op deze wijze verkregen vrouw gelijk behandelt als zijn eigen vrouw. Hij mag niet - zó́ luidt de beeldspraak - met haar doen als iemand die een bamboe splijt, de eene helft er van daarbij na zich toetrekkend, terwijl hij op de andere helft zijn voet gedrukt houdt. Intusschen is hij niet verplicht die vrouw als de zijne tot zich te nemen; hij kan zulks weigeren en dan gaat ze over naar een der andere naaste bloedverwanten van haar overledeu man en als ook geen van dezen daartoe genegen is, kan ze teruggaan naar haar vader of diens verwanten of ook wel naar haar zoon. Ook gebeurt het, dat ze bij den broeder van haar overleden man intrekt, terwijl ouderdom als anderszins haar belet echtelijk met hem samen te leven; in dit geval verbiedt de aả dat haar zwager haar afwijst.

Het huisgezin noemt men saoemo. De vader (bopo) is het hoofd van het gezin en de beheerder van deszelfs goederen. Hij heeft de koorden van de beurs in handen of - zooals de Loeboe het uitdrukt - hij is degeen, die het touw van het werpnet hanteert (si gomgom toli pabonton). Terwijl volgens de adat de verhouding tusschen de vrouw en haar schoonvader - welke verhouding amang woboe heet - niet toelaat, dat zij in elkaars gezelschap zijn en ook tusschen den man en zijn schoonmoeder een dergelijke verhouding van terughoudendheid geldt -- die men inong toebang noemt bestaat tusschen schoonvader en schoonzoon of tusschen schoonmoeder en schoondochter zulk een discretie voorschrift niet. Komt een man b.v. zijn schoondochter tegen, dan zal hij direct naar den tegenovergestelden kant van den weg oversteken om haar zoover mogelijk te laten passeeren en is de weg zeer smal, dan zorgt hij er wel voor tijdig de plat te poetsen.

Is een Loeboe overleden en is dit aan zijn mannelijke en vrouwelijke verwanten bekend gemaakt, dan gaan dezen naar het sterfhuis en geven daar nabij gekomen een geweersalvo af. Van uit het sterfhuis wordt dit met een dergelijk salvo beantwoord. De vrouwen brengen allen wat brandhout mede voor het te bereiden offermaal. Terwijl de mannen beneden het huis van den overledene blijven tabak rooken, gaan de vrouwen naar binnen en heffen daar 
luid huilende klangzangen aan (mangandoeng), hetgeen voortduurt tot de afwassching van het lijk heeft plaats gehad. Dit geschiedt door een drietal vrouwelijke verwanten, die daartoe zittende plaats nemen en het lijk kruislings over haar uitgestrekte beenen neerleggen. Daarna wordt het lijk in een lijkkleed (koin dibobo moti ook wel koin pingah = wit kleed) gewikkeld. Nadat de geestelijke (pagawei) vervolgens een gebed heeft gepreveld, wordt de lijkbaar (pòwò-pòwò) beneden het huis klaargezet. Een doodkist wordt niet gebruikt. Als het lijk naar het kerkhof (koeboevan) wordt weggedragen heffen de vrouwen op nieuw klaagliederen aan. Na de begrafenis keert men naar het sterfhuis terug, waar men zich aan een offermaaitijd (kandoewi) vereenigt. Eerst eten de mannen, daarna de vrouwen. Zeven dagen na het overlijden heeft er op nieuw een kandoewi plaats. Het lijk wordt op de zij liggende met het hoofd naar het noorden begraven. De oude graven uit den heidenschen tijd hebben een ligging oost-west. Boven het graf is een lage grafheuvel (pondom) aangebracht, aan de uiteinden waarvan een paar rechtopstaande grafsteenen (botoe pahatondo $=$ merksteenen). Elk jaar worden de graven ééns schoongemaakt. Oude graven van si laso's worden als kramatplaatsen (pakaoelan) vereerd. Na ziekteherstel of andere belaugrijke gebeurtenissen worden daar offers gebracht ter vervulling van vooraf gedane beloften (mambao kaoel). $\mathrm{Na}$ het doen van zulk een belofte is het gebruikelijk dat op het graf een klein wit vlaggetje (pondji-pondji) wordt geplant.

Verliest een vrouw haar man of een moeder haar kind door den dood, dan laat ze bij wijze van rouw gedurende zeven etmalen haar baadje uit en draagt slechts een stuk goed om den schouder (batodjong).

Zagen we hierboven hoe de echtelijke band wordt gesloten, thans rest een enkel woord over de ontbinding van het huwelijk en hare gevolgen ten aauzien der goederen.

Echtscheidingen (sibang) zijn bij de Loeboe's zeldzaam. Deels is dit een gevolg van de omstandigheid, dat de vrouwen groote vrijheid wordt gelateu om over haar hand te beschikken, deels dáárvan, dat de staat van dienstbaarheid, waarin de jonge man tegenover zijn schoonouders staat den Loeboe niet zoo lichtvaardig tot een huwelijk doet besluiten.

Komt het verzoek om echtscheiding van de zijde van de vrouw, dan gaan de voor haar betaalde koopprijs en ook de uit deze ver- 
bintenis verwekte kinderen naar den man; gaat het verzoek van deze uit, dan blijven eveneens de kinderen bij hem, maar de bruidschat ontvangt hij dan niet terug. Alleen als de vrouw bij de echtscheiding zwanger was, blijft het kind na de geboorte bij haar als het een meisje is; blijkt het een jongen te zijn, dan gaat het later naar den gescheiden man terug.

Als teeken dat het huwelijk onvoorwaardelijk ontbonden is, wordt de vrouw, op het oogenblik dat zij het huis van haar man verlaat, een slip van een zwarten doek in handen gegeven, die reeds gedeeltelijk middendoor is gescheurd. De man houdt het andere uiteinde vast en scheurt de slippen vaneen. De beteekenis dezer plechtigheid is, dat even als die doorgescheurde kain nooit weer één kan worden, man en vrouw verder voor altijd gescheiden zullen zijn.

De vrouw kan niet erven en evenmin kan zij een erflating doen. Zelf niets bezittende is zij een voorwerp van bezit van haar man. De regel is, dat als een man sterft, de erfgoederen (bawang panadingan, vg. Mandel. tinadingan; tading = datgeue, wat achterblijft) onverdeeld overgegaan op zijn oudsten zoou. Heeft de overledene geen zoon nagelaten, dan gaan zijn goederen over naar zijn oudsten broeder (kòkò). Erflatingen bij testament - die in Mandailing wèl voorkomen - kent de adat niet, althans de Loeboe heeft er een af keer van. "Wie een testament nalaat" - zóó drukt hij zich uit "is als een zwaluw (lajang ${ }^{2}$ ), die met moeite haar voedsel heeft gezocht; wie een testament ontvangt is als de luie larve van de klappertor (hedo), die zijn voedsel niet behoeft te zoeken, maar zich dik zuigt aan den klapperbloesem (lajang-lajang na hando, hedo na gapok).

Zooals we zagen gaat de weduwe als regel over naar een jongeren broeder van haar overleden man. Komen uit deze nieuwe verbintenis kinderen, dan hebben deze geen rechten op de nalatenschap van den overledene.

Kinderen buiten het huwelijk geboren erven niet.

Van pleegkinderen wil de Loeboe niets weten, hij noemt ze verachtelijk wespenkinderen (honok angkoet-angkoet).

\section{Godsdienst. Bijgeloovige practijken. Ziekten en HARE BESTRIJDING.}

Hoewel de Loeboe's thans allen in naam den Islam aanhangen, zoo ligt heel hun godsdienstig, zedelijk en maatschappelijk leven nog besloten in de oude heidensche geestenvereering. Een bijzondere 
vereering geniet de geest vau Singa Tandang, hun vroeger stamhoofd, bij gevaren en ongevallen roept men hem aan. Maar verder onderscheiden zij nog tal van andere geesten, goede en kwade.

Volgens de begrippen der Loeboe's zijn 's menschen ziel (tondi) en lichaam tijdens het leven innig met elkander verbonden. Wèl kan de tondi tijdelijk het lichaam verlaten, bijv. in den droom. Bij den dood scheidt de ziel zich duurzaam van het lichaam af en verkrijgt dan als soemangot een persoonlijk voortbestaan in het zielenland Bata digintjat (lett: goden van de bovenwereld). Vandaar kan de soemangot naar de aarde terugkeeren om de menschen kwaad te doen of tijdelijk in een dier over te gaan (solopan). Hoort de Loeboe b.v. een moesang (palmmarter), dan is hij in doodsangst, denkende, dat hij dan het geluid hoort van een soemangot, die in dat dier is gevaren.

Men kent allerlei middeltjes om zich tegen de ongewenschte bezoeken der soemangot's te vrijwaren. Is men b.v. in het bosch de route kwijt, dan meent men, dat zulks het werk is van een soemangot, die den wandelaar op de hielen zit en hem het gezichtsvermogen beneveld houdt. Om nu dien kwaadwillenden geest het spoor bijster te maken, neemt men een stuk rotan, dat men in het midden doorsplijt. Door den rotan te buigen, ontstaat dau een opening, waar men doorheen kruipt, waarna de rotan weer schielijk wordt gespannen, en de opening zich sluit. Zóó doende kan de geest - naar men meent - de opening niet terugvinden en dus zijn slachtoffer niet verder vervolgen.

Tot het wèlslagen van allerlei oudernemingen wordt zeer gelet op gelukkige en ongelukkige dagen en tijdstippen, waartoe men den stand der sterren raadpleegt, in het bijzonder van de sterrenbeelden Ala Godang en Ala Soentjang.

On zich in den tijd te orienteeren neemt men allerlei hulpmiddelen te baat. Zijn b.v. de vruchten van den pinang alle geel, dan is dit een bewijs, dat men in de zevende maand van het jaar leeft; in die maand ook maakt de bangkoewiwik (een insekt, dat onder den groud leeft) zeven openingen in den grond enz. enz.

De begrippen omtrent het wereldal zijn zeer primitief. De wereld (tanah) stelt men zich voor als een plat vierkant vlak, aan elk der hoeken door een rund (lomboe) gedragen. Wordt één dier runderen door een horsel (oentoeng ${ }^{2}$ ) gestoken, dan beweegt het dier zich en ontstaat aardbeving. De sterren noemt men honok boelan d.i. kinderen der maan. Van de zon makt hun phantasie zich geen bijzondere 
voorstelling, ook van haar op- en ondergaan, geven de Loeboe's zich verder geen rekenschap. Van een scheppingsverhaal is niets bekend. Voor onweer (wonggoeb) en bliksem (ilap) zijn zij zcer bang, zij vluchten dan in hun huizen. De bliksem denken zij zich als een reuzezweep in handen der booze geesten.

$\mathrm{Bij}$ langdurige droogte tracht men regen op te wekken door het baden van een kat (mamondikan kotjeng). Een ander middel om den regen te lokken bestaat hierin, dat men een pisangstam in de rivier plant (manjoewan batang pesang). Door den stroom aldus een beletsel in den weg te leggen, meent men dat hij spoedig voor den noodigen regen zal zorgen om het rivierwater voldoende stuwkracht te geven om dat beletsel op te ruimen.

$\mathrm{Om}$ zijn onschuld te bewijzen kent de adat de volgende zuiveringseed. De beklaagde werpt een kip, warvan de pooten vastgebonden en de bek en het achterdeel dichtgenaaid zijn, levend in het vuur, daarbij de volgende verwensching over zich zelf uitsprekend: "Moelo koepaboewa..... ma ajom ondja okoe motino, ma ajom na idjoi moeloeidno on na idjoi oedjoeng pabikno" d.w.z. "als ik..... doe, zal het mij gaan als deze kip en zal ik sterven als deze kip, wier bek en achterdeel zijn dichtgenaaid".

Als voornaamste oorzaken tot het ontstaan van ziekten worden aangemerkt de invloed van kwaadwillige gcesten (die òf het lichaam van patient binuendringen of het van buiten geweld aandoen) en van wormen en verder de tooverkracht waardoor men in staat is zijn medemensch ziek te maken. Die ziekteverwekkende geesten zijn in de eerste plaats de soemangot's van afgestorvenen en wel voornamelijk van die afgestorvenen, die de genoegens des levens niet of slechts ten deele hebben genoten. Daarover misnoegd trachten ze ook anderen deelgenooten te maken van hun lot. Tot die naijverige zielen behooren b.v. die van doodgeboren kinderen, van personen die niet den natuurlijken dood gestorven zijn (b.v. tengevolge van een of ander ongeluk), van in het kraambed overleden vrouwen enz. Wanneer nu de Loeboe zijn medemensch kwaad wil doen, zal hij allereerst trachten, die bij uitstek gevreesde zielen aan zijn booze praktijken dienstbaar te maken. Zulks kan hij niet zelf doen, maar daarvoor heeft hij de tusschenkomst noodig van den dotoe, den persoon die geacht wordt in staat te zijn met de geesten in direct verkeer te komen, hunne bedoelingen te doorgronden, te exploiteeren, dan wel krachteloos te maken. Deze denkbeelden hebben het aanzijn gegeven aan een gruwzaam systeem van tooverij en beheksing, 
waarvoor de Loeboe's bij de omwonende stammen (Malciers en Maudailingers) berucht en gevreesd zijn.

Naar het volksgeloof wil, kan de dotoe b.v. uit een foetuslijkje een krachtig werkend toovergif maken. Men kan dit gif direct aanwenden door het b.v. onder het prevelen vau verwenschingen in iemands eten te mengen of indirect door het te begraven onder het huis van den persoon, dien men treffen wil. In beide gevallen is de werking doodelijk. Ziehier het recept, dat mij door een dotoe voor de bereiding van dat gif werd aan de hand gedaan. Men laat het foetus eerst op een scherf van een gebroken rijstpot (tabingko pabeo) boven een zacht vuurtje indrogen, daarna het droge residu fijn wrijven (manggeleng) en vermengen met de asch van de verbrande bandeu, warmede het lijkkleed van een door een gewelddadigen dood overledene (owang moti sowi vg. Mandel. mate sadari = zij die gestorven zijn in één dag) gewikkeld is geweest, met fijne plantaardige haartjes, met het sap uit de stengels van den waringinboom (kojoe owo) en met het bloed van een roode kip (dawah sikapal nasiwah). Dit mixtum wordt in een dunne bamboe prapat geborgen, die daarna met een kurk van plantenmerg wordt gesloten. Deze bamboe wordt gedurende $7 \times 7$ dagen begraven en om de 3 dagen spreekt de dotoe over dit graf een doa uit, waarvan de hoofdzaak hierin bestaat, dat hij telkens aan zijn verborgen schat vraagt, om toch spoedig in panjiat's te willen veranderen d.z. kleine insekten, niet grooter dan mieren, die een snerpend, vèrdragend, geluid kunnen doen hooren. Naar men meent, kan men die diertjes niet anders machtig worden, dan door ze op bovenbeschreven geheimzinuige wijze te cultiveeren, waartoe intusschen alleen de dotoe in staat is. $\mathrm{Om}$ als gif te diewen moeten die panjiat's eerst weer gepoft en daarna fijn gewreven worden.

Een zeer gevreesd en zeer bekend toovermiddel is verder de z.g. benang menaloe d.i. een draad afkomstig van de banden, waarmede het lijkkleed van een z.g. owang moti sowi (zie boven) is gesloten geweest. Het spreekt van zelf, dat men zulk een draad alleen door tusschenkomst van den dotoe tegen grof geld kan bekomen. Dien draad spant men tusschen ring- en middenvinger van de linkerhand en gaat hiermede de woning binnen van het voorwerp zijner wraak, knoopt hiermede een gesprek aan en houdt ongemerkt even de hand bij het haardvuur, strekt vervolgens de beide bedoelde vingers uit, waardoor de draad zich spant en deze door het vuur even verwarmd wordt. De uitwerking van deze eenvoudige handeling heet onfeilbaar 
te zijn; evenals die draad zich spande, zóó zal ook de lintworm zich spannen in het lichaam van zijn slachtoffer, waarvan een heftige bloeddiarrhee het gevolg zal zijn. Ook de Loeboe's gelooven namelijk, dat zich in ieder menschelijk lichaam nabij den navel één lintworm bevindt (golong wajo). Het toovermiddel is in dit geval dus een sympathetisch middel.

Trouwens de meeste toovermiddelen der Loeboe's zijn er op angelegd, om niet den delinquent zelf direct te treffen, maar om dit langs een omweg te doen b.v. door van hem een beeldje (soempaman, lett.: evenbeeld) te maken, dat men daarna op allerlei manieren mishandelt, denkende, dat die mishandelingen dan sympathetisch op zijn vijand overgaan.

In den regel maakt men dan twee beeldjes b.v. één van klei en één van hout, het eene wordt begraven onder het huis van den persoon, dien men benadeelen wil, het andere smeert men op de hartstreek in met spaansche peper, of men steekt op die plaats eenige naalden in het beeld; soms ook hangt men het aan een touw en schommelt het daarna heen en weer, opdat de persoon, die het beeldje voorstelt, eveneens door aanvallen van eclampsie heen en weer zal schudden.

Ook zijn er voorbeelden, dat men zijn medemensch ziek kan maken door het bemachtigen van iets wat hem toebehoort (b.v. een kleedingstuk, zijn haar, nagels, speeksel enz.) of wat met hem in aanraking is geweest.

Vindt een minnaar bij de vrouw zijner keuze zijn liefde niet beantwoord, dan is dit reeds dikwijls een reden tot wrakneming. De dotoe, wiens hulp in dat geval in het geheim wordt ingeroepen, is ook hier de handelende persoon. Hij begint van een weinig aarde, dat van het kerkhof af komstig moet zijn, een beeldje te maken, de onwillige vrouw voorstellende. Dit beeldje wordt in een witte doek gewikkeld op gelijke wijze als men een lijk inwikkelt. Daarna maakt hij een mengsel van allerlei jeukveroorzakende, van planten af komstige haartjes, (o.a. van den bamboe), waarmede de pop wordt bestrooid. Vervolgens verschaft de dotoe zich een weinig aarde van de plaats, waar de vrouw het laatst heeft geurineerd, verder een paar lokjes van haar haar, eenige afknipsels van haar nagels en eindelijk nog eenige rijstkorrels, die zij bij het eten heeft gemorst. Van deze ingredienten wordt een mixtum gemaakt en op de pop neergelegd. De bedoeling van dit een en ander is (de dotoe laat die bedoeling in zijn tooverformulieren duidelijk blijken), dat den 
boozen geest - van wiens hulp de dotoe zich hier bedient - ter dege wordt ingeprent, hoe de haren, nagels enz. van de vrouw er uit zien, opdat hij niet lang zal behoeven te zoeken, wie hij met ziekte treffen moet. Daarna zoekt de dotoe een bladnerf van den arenpalm en wel van een blad, dat zich voortdurend heen en weer beweegt, terwijl de zich daarbij bevindende bladeren in rust zijn. Aan de bladeren als hier bedoeld wordt een magische beteekenis toegekend, vooral aan de nerven dier bladeren; de Loeboe noemt ze lidi na lalajan d.w. z. krankzinnige nerven. Met die nerf wordt het beeldje een heelen dag en nacht lang geslagen. Vervolgens wordt het een etmaal gekookt in een trogvormig uitgehold stuk hout (palangka); het borrelen van het kokende water geeft de convulsies weer, die bij de patiënte zullen optreden. Daarop wordt de pop gedurende een gelijk tijdsverloop boven vuur gerookt en dan in een soort loodsje ondergebracht, terwijl de dotoe met zijn helpers daaromheen plaats nemen. Elk heeft daarbij zijn bijzondere taak, de een maakt de pop telkens aan het schrikken, de ander moet die voordurend slaan enz. Is het vau al deze kunstgrepen verwachte succes bereikt, dan vervalt de patiënte tot een soort waauzin, dien men si imbo toemoeboeng noemt (lett. de siamangaap op den nok van het dak). Deze zielsziekte - te vergelijken met het si djoendei der Maleiers uit zich dáárin, dat de persoon in quaestie met uitgestoken tong en rood beloopen oogen zich als een razende anstelt, steeds zingt, geen personen herkent of hoort, haar kleedingstukken stuk scheurt, alles in de buurt vernielt, zich de haren uittrekt, de boomen inklimt enz. De ziekte treedt in telkens terugkeerende aanvallen op, waarin de patiënte eten noch drinken wil.

De dotoe laat zich voor al zijn trucs duur betalen, in het laatste geval b.v. beloopt zijn honorarium f 15 tot f 100 en meer.

De familieleden van de ongelukkige vrouw gaan ten einde raad naar een anderen dotoe om hulp, die op zijn beurt de noodige hocus-pocus in zijn mars voert om de patiënte van bedoelde ziekte te verlossen. Daartoe perst hij een drietal citrussoorten (limau) in water uit (manggepoe) ouder het uitspreken van tooverformulieren $(d o a)$; daarna neemt hij eenige bepaalde kruiden, prevelt daarover weer een dergelijk formulier (tawa) en kauwt die. Met dit kauwsel worden oogen en borst van de vrouw bespuwd (nitoelbaskon). Vervolgens werpt men een deken over haar heen, terwijl onder die deken sabi-zaad wordt gebrand hetgeen een sterken stank verspreidt. De bedoeling van dit laatste is den ziekteverwekkenden geest, die 
in het lichaam van de vrouw is gevaren (in casu de geest Sidang Béla Markahakkahak) te dwingen naar buiten te treden. Na eenigen tijd gaat de patiënte sterk hoesten. Dit is, naar men meent, het oogenblik dat de kwelgeest haar lichaam heeft verlaten. De deken wordt nu weggenomen en bestaat de kuur, die drie maanden duren moet, verder dárin, dat zij zich met bovenbedoeld citroenwater dagelijks drie maal per dag moet overgieten. Een kenmerkend verschijusel dezer ziekte is nog, dat de getroftene zware hoofdpijnen krijgt in het voorhoofd, meer speciaal aan de fontanel (amboeboe), de plaats dus in den schedel, die bij pasgeborenen nog niet door gebeente is gesloten. Men stelt zich voor, dat op die plats de booze geest het licham van zijn slachtoffer is binnengedrongen eu daaruit het lichaam ook weer verlaat.

Een andere psychose, door magische invloeden veroorzaakt welke bij beide sexen voorkomt is het si-palit-gilo. Ook hier treedt de ziekte in aanvallen op en stelt de persoon zich als bezetene aan, hij holt als een razende voort, wil het raam uitspringen enz. Een eigenaardigheid dezer ziekte is, volgens mijn zegslieden, dat zij op andere personen, die den patiënt naderen, overgaat. Tegen die besmetting kau men zich echter beveiligen door van den dotoe eeu afweermiddel (tangkal) machtig te worden, bestande in eenige kruiden, waarop men kauwen moet. Ook hier zijn de ziekteverwekkende kunstgrepen van den dotoe gelijksoortig aan die bij het si-imbo-toemoeboeng gebruikelijk, terwijl ook hier het antidotum tot zijn professioneele geheimen behoort.

Kropgezwellen (bawoet) komen veelvuldig voor. Men meent, dat deze aandoening der schildklier veroorzaakt wordt door het drinken van water, dat vermengd is met het sap uit de vruchten van de taboe loemboeng, een klimplant, die bij voorkeur an rivieroevers groeit. Als de zeer groote roode vruchten van deze plant rijp zijn, barsten ze open en scheiden dan een vloeistof af, die men garodir noemt.

Hoewel de bevolking in de vallei van Mandailing voortdurend door de beruchte Mandailingsche koortsen wordt bezocht, komen deze malariakoortsen (pialoe) in de Loeboesche nederzettingen nagenoeg niet voor, waarschijnlijk door het gemis van sawah's en vischvijvers aldaar. Inwendige middelen zijn tegen deze ziekte niet bekend. Bij koortsige aandoeningen wikkelt men de duimen en teenen in met fijngemalen spaansche peper, of wel mes wrijft de gewrichten in met het sap van de stengels van de biwa si papan, vermengd met kalk. 
Allerlei ingewands- en andere ziekten worden op rekening gesteld van ingewandswormen (panjakéh golong ${ }^{2}$ ). Reeds van af de geboorte wordt de mensch geacht in zijn lichaam allerlei wormen te huisvesteu. Gaan die dieren door zekere invloeden rondkruipen en strengelen zij zich door elkaar heen, dan is ziekte daarvan het gevolg. Ook buikrommelingen worden b.v. op die wijze verklaard. Als geneesmiddel tegen deze soort zickten geldt o.a. een aftreksel van de z.g. golong ${ }^{2}$ een wortelsoort, die met hare vertakkingen op een dicht kluwen ineengestrengelde wormen gelijkt. Het geneesmiddel en de kwaal ziju hier dus van dezelfde soort.

Iedere droge mediciju noemt de Loeboe daon. Op onze daon's is hij zeer gesteld, vooral op chinine (daon damam) en phenolum (aoe boesoek), welke laatste hij liefst onvermengd gebruikt tegen framboesia op het lijf (poewoe) en aan de voetzolen (pamantosan).

\section{Middelen van bestaan.}

Door het zeer laag maatschappelijk standpunt waarop dit volkje staat, zijn zịne daaruit voortspruitende behoeften ook uiterst eenvoudig. Daarbij ziju de Loeboe's - als gezegd - afkeerig van allen inspannenden arbeid, of liever zij zijn tevreden met hun primitief bestaan en missen daarom den prikkel om hun toestand te verbeteren. Pogingen van bestuurswege gedaan om hen humne haardsteden van de veraf gelegen berghellingen naar de vlakte te doen overbrengen hebben steeds gefaald: hun hart trekt hen altijd naar hun armoedige hutten op humne ladangs terug. Hun middelen van bestaan hebben, zooals dus voor de hand ligt, noy een zeer nomadisch karakter.

De sawahbouw is hun onbekend; de terreinen hunner nederzettingen zijn daartoe trouwens ougeschikt. Op hun ladangs cultiveeren ze als voedingsgewassen rijst (podi) en mais (djagang) en verder nog kuolgewassen, kool en peulvruchten. Verder verbouwen ze in geringe mate tabak en koffie. Nabij hun hutten vindt men meesial eenige vruchtboomen geplant. De meeste dier landbouwproducten dienen voor eigen consumptie.

De tijdstippen van planten (mobdang) eu oogsten (manggotol) van de rijst worden met vroolijke feesten gevierd. Bij het uitplauten van de rijst zijn alle verwanten bijeen, de mannelijke familieleden krijgen elk een aangepunten stok van een vadem lengte orn de plantgaten te maken, de vrouwen brengen de zaadpadi mede en strooien die 
in de gaten uit. Voor het afsnijden der rijpe rijsthalmen wordt geen werktuig gebruikt, maar geschiedt dit eenvoudig met den nagel. Het ouderling hulpbetoon bij het planten en oogsten noemt men manjawojo. $\mathrm{Na}$ afloop der werkzaamheden vereenigt men zich tot een feestmaaltijd.

Buffels, runderen of paarden vindt men bij de Loeboe's niet, de veeteelt blijft daarom tot eenige geiten en wat pluimvee beperkt.

De nijverheid is van uiterst geringe beteekenis en bepaalt zich tot eenige artikelen van dagelijksch gebruik. Zoo trefı men ouder hen eenige smeden en mattenmakers aan, maar hun werk is zeer grof. Verder houden veel vrouwen zich bezig met het uitpluizen van de zwarte haarachtige stof (hédjo), groeiende tusschen den stam en de bladstelen van den arenpalm en met het maken van touw daarvan (poejoean).

Jacht en visscherij worden uitsluitend als tijdverdrijf of tot eigen voeding beoefend. Op groot wild, zooals olifanten (godjo), neushoorns (badak) en tijgers (hawimau) wordt geen jacht gemaakt, wèl op herten (woeso), wilde zwijnen (bobi) en dwergherten (idjang). Men vangt die dieren vooral met soorten van strikken (tindjak en djawing) en makt ze daarna met lansen (boebingan) af. Om varkens uit zijn ladaugs te houden plant men wel fijn aangepunte bamboe's in den grond, die men baséh noemt. Vogels en vliegende honden (kaloeong) worden met netten (wambang) gevangen. Heeft men eeu hert bemachtigd, dan krijgt ieder, die aan de jacht heeft deelgenomen een bepaald door de adat angewezen stuk van het wild n.l. degeen, die den strik gespannen heeft het hoofd, de radja een achterpoot (sangkaé), het ripéhoofd een schouderblad (halepkep), hij die het spoor vond een pijpbeen (pabasbas), hij die den eersten lansstoot gaf (sipanggoegah) drie ribben (bòsòh) met een stuk hart en lever. Wat er dan nog van het wild overblijft wordt verdeeld aan de jachthonden, die aan de drijfjacht hebben deelgenomeu. Wordt een wild zwijn geschoten, dan wordt het vleesch als delicatesse verorberd.

Het vangen van visch (hekan) uit de riviertjes geschiedt vooral met schepnetten (mandowong bonggah), hengels (mangkoil) en middels afdammingen (sabih) van de rivier; in het laatste geval wordt de vischschool opgedreven naar een in hellend vlak opgestelde bamboe zeef, waarop de visch blijft liggen. Een eigenaardige wijze om kleine visschen te vangen is nog deze: men plant in den rivierbodem een soort hengels, aan het koord waarvan echter niet een haak is bevestigd, maar een bladscheede vau den arenpalm, die men tot een 
soort peperbus heeft omgevouwen. De vischjes, die gaarne schaduw opzoeken kruipen daarin. Tegen den avond worden die peperbussen schielijk opgeschept en de daarin verscholen vischjes zoodoende gesuapt. Fuiken (bòbò) zijn bij de Loeboe's wel bekend, maar men makt er geen gebruik van.

Van veel meer belang dan een der genoemde middelen van bestaan is de inzameling van boschproducten, waarvan verschillende soorten op de inlandsche markt worden verhandeld. Daartoe behooren tal van houtsoorten, rotan, wortels, eetbare vruchten, melksappen (gatah), damarhars, geneeskrachtige kruiden enz. Het timmerhout wordt vooral als planken ter markt gebracht. De meest gezochte houtsoorten zijn bania, ingoel (vg. Mandel. soerian) en mawanti. Het bekappen van het hout geschiedt zeer primitief; is de boom omgehakt (ditabang) en neergeveld (mabobo), dan wordt de stam middels een houten wig middendoor gespleten (dibodji-bodji), elke helft op gelijke wijze weer in de helft enz., totdat het gewenschte aantal planken van de vereischte dikte is verkregen. Daarna worden die planken met een dissel (baleong) zooveel mogelijk effen gekapt (ditawa). Van de damarhars (dama) - die door inhakking in den stam (ditabang-tabang) wordt verkregen - worden kaarsen (dama balongging) gemaakt die het gewone verlichtingsmateriaal uitmaken in de Loeboesche hutten. Die kaarsen zijn zeer goedkoop, men koopt er twee voor ééne duit en ze branden ongeveer zes uren. Voor het inzamelen van gĕtah gaat men zeer roekeloos te werk: de boom wordt eerst in zijn geheel omgekapt en eerst daarna worden inkervingen in de bast gemaakt, waar de gom uitvloeit, die zich daarna verhardt. Die gĕtah wordt eerst gekookt en daarna worden er ballen van gemaakt (dipahebol vg. Bat. hiboel= rond). Dat de Loeboe op het punt van handel een ruim geweten heeft, blijkt wel hieruit, dat de handelaren die ballen altijd eerst openbreken alvorens ze op te koopen, daar ze zeer dikwijls van binnen met steenen en stukken boomschors zijn opgestopt, terwijl alsdan rijstepap (boeboeh bawah) als bindmiddel voor die ongerechtigheden wordt gebezigd. Tot de uit de bosschen gewonnen eetbare vruchten zijn te vermelden baboewas, andis, opong, salak, woewam, palpal, kapondong enz. Geurige wortelsoorten zijn daoepah en si tanggis. Van de ingezamelde boschproducten ontvangen de hoofden een tiende, welke retributie soba wordt genoemd.

Panjaboengan 1910.

Dl. 66 . 


\section{Bijlage I.}

OverZich't VAN HE'T aAN'TAL LOEBOE'S EN HUNNE NEDERZETTINGEN in Mandailing.

\begin{tabular}{|c|c|c|c|c|c|}
\hline \multirow{2}{*}{$\begin{array}{l}\text { District } \\
\text { [koeria]. }\end{array}$} & \multirow{2}{*}{ Kampoeng. } & \multirow{2}{*}{ Nederzettingen. } & \multicolumn{2}{|c|}{ Zielental } & \multirow{2}{*}{$\begin{array}{l}\text { Wo- } \\
\text { ningen. }\end{array}$} \\
\hline & & & Mannel. & Vrouwel. & \\
\hline \multirow[t]{3}{*}{ Goenoeng Toewah } & Ipar Bondar . . . & Sopo Batoe ... & 48 & 4.5 & 16 \\
\hline & Goenoeng Toewah & Si Alapajoeng. . & 32 & 25 & 16 \\
\hline & & Baroehoer . . . . & 33 & 31 & 22 \\
\hline \multirow[t]{4}{*}{ Goenoeng Baringin } & Goenoeng Baringin & Pagaran Babi. . & 132 & 132 & 64 \\
\hline & & Pagaran Karambir & 84 & 104 & 40 \\
\hline & & Pagaran"Gala ${ }^{2}$. & 76 & 69 & 33 \\
\hline & & Tobing Naindjang & 95 & 116 & 44 \\
\hline \multirow[t]{4}{*}{ Kota Siantar } & Kota Siantar . . . & Si Obon..... & 72 & 77 & 37 \\
\hline & & Aek Mata.... & 81 & 109 & 56 \\
\hline & Pidoli Lombang : & Si Papaga / 胥 & 80 & 82 & 4.5 \\
\hline & & Aek Banir & 193 & 209 & 106 \\
\hline 一 & - & Totaal ... & 926 & 999 & 4.79 \\
\hline
\end{tabular}




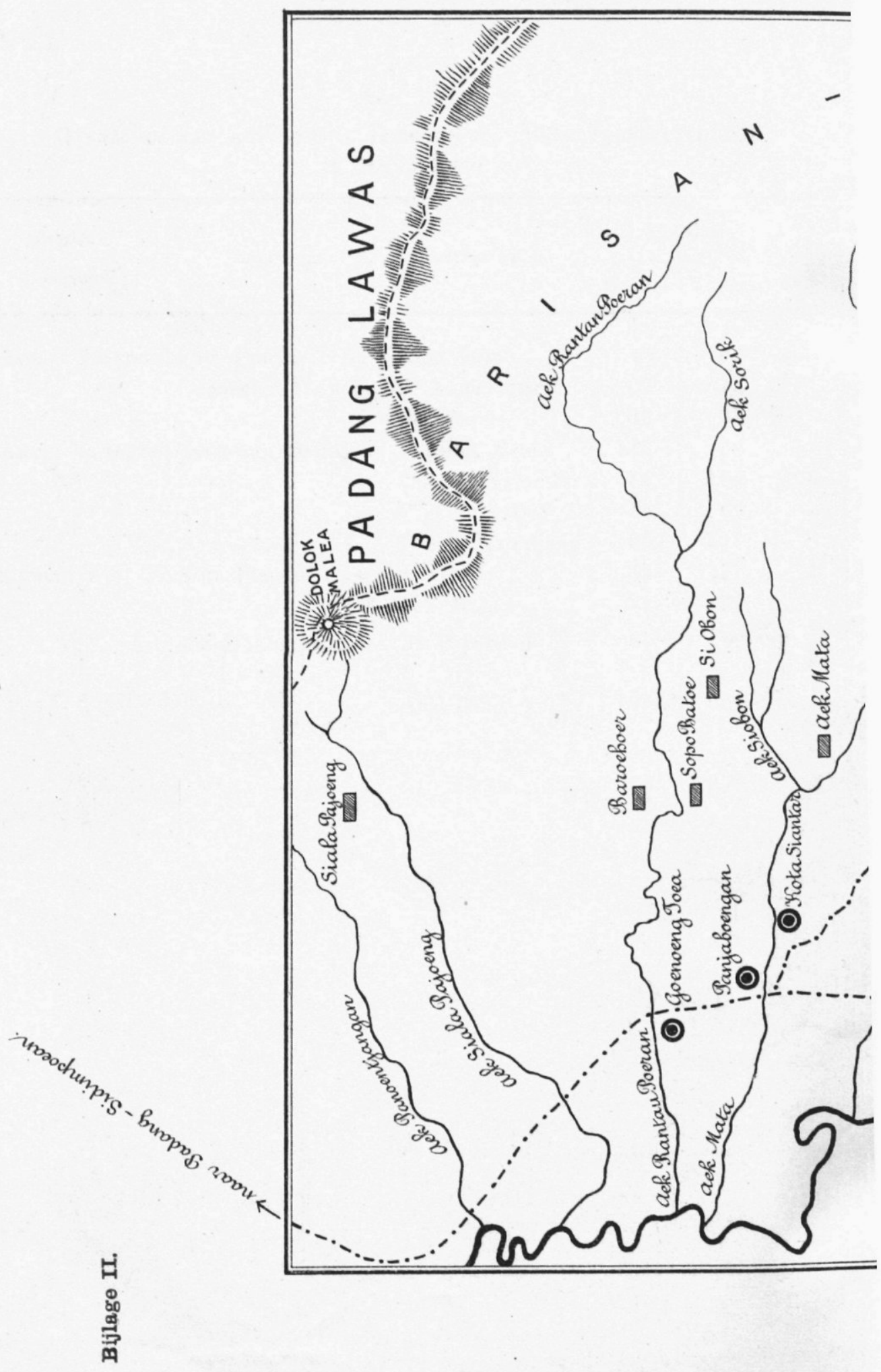




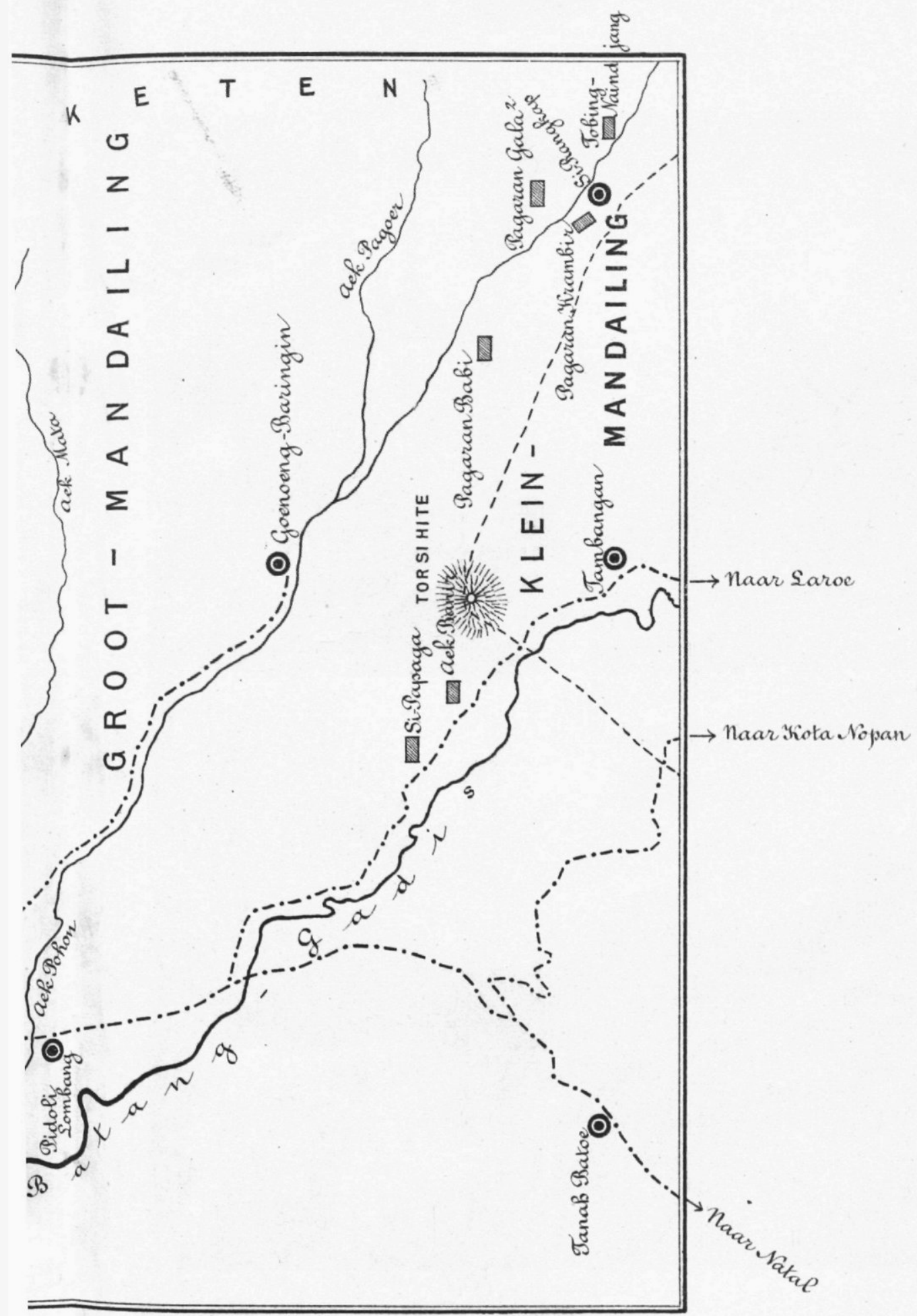




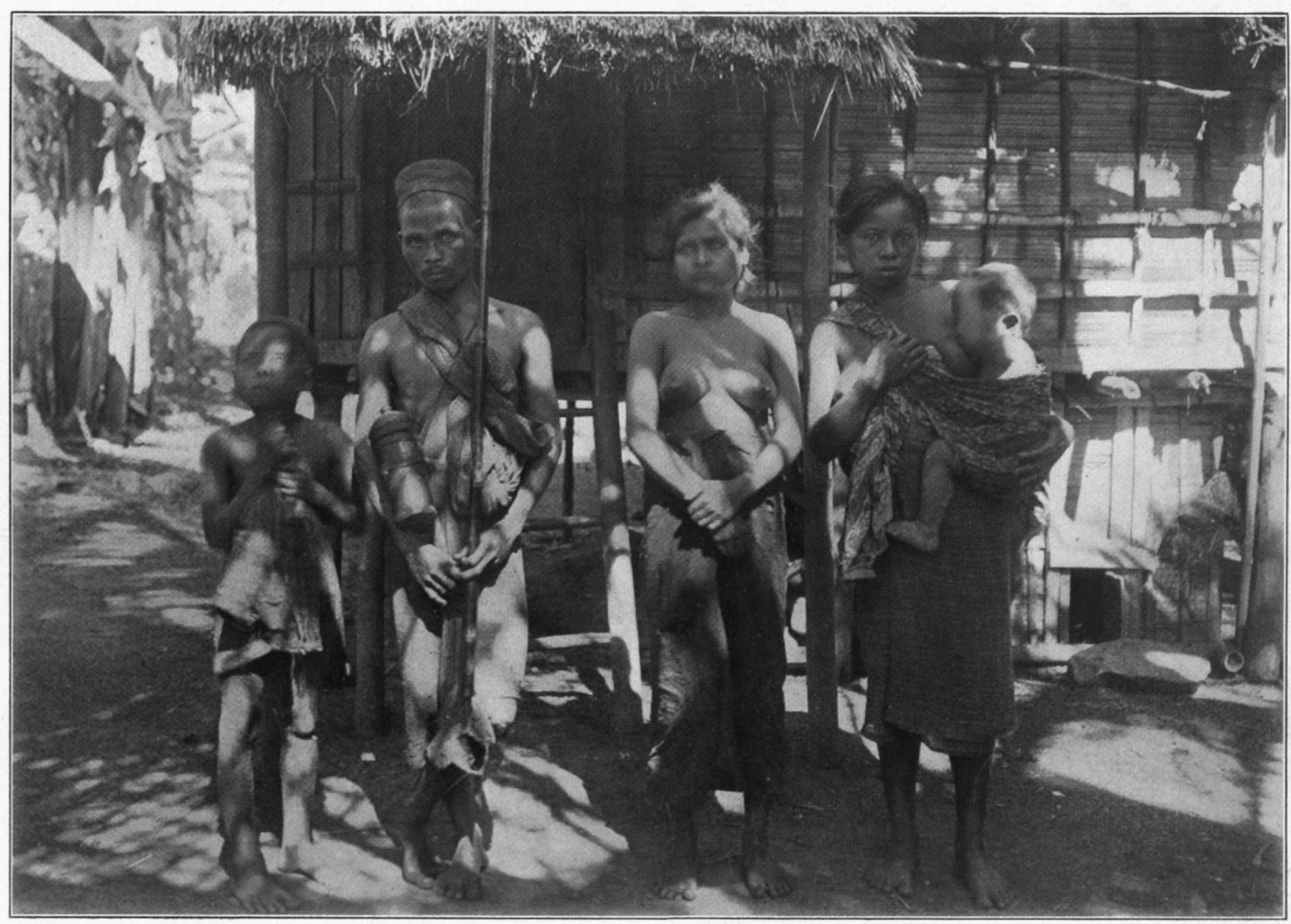

